Research Article

www.ijrap.net

\title{
A STUDY ON THE IMPACT OF CHEMICAL PRESERVATIVES ON SENSORIAL EXCELLENCE OF BREAD AT VARIOUS TEMPERATURES
}

Muhammad Shahnawaz ${ }^{1 *}$, Dileep Kumar Lohano ${ }^{2}$ and Saghir Ahmed Sheikh ${ }^{2}$

${ }^{1}$ Department of Food Technology, Karakoram International University Gilgit, Pakistan

${ }^{2}$ Institute of Food Sciences and Technology, Sindh Agriculture University, Tandojam, Pakistan

Received on: 02/09/12 Revised on: 23/10/12 Accepted on: 12/11/12

\author{
*Corresponding author \\ E-mail: nawaz_glt@yahoo.com \\ DOI: 10.7897/2277-4343.03631 \\ Published by Moksha Publishing House. Website www.mokshaph.com \\ All rights reserved.
}

\begin{abstract}
A critical study was carried out to evaluate the impact of chemical preservatives on the sensorial excellence of bread at various temperatures. The entire experiment was undertaken in the Institute of Food Sciences and Technology, Sindh Agriculture University, Tandojam in 2011. Two types of preservatives i.e. calcium propionate $(\mathrm{CP})$ and calcium lactate $(\mathrm{CL})$ at $14{ }^{\circ} \mathrm{C}, 22{ }^{\circ} \mathrm{C}$ and ambient temperature $\left(32{ }^{0} \mathrm{C}\right)$ were investigated. The results revealed that both the preservatives at a level of 0.4 and $0.8 \mathrm{~g}$ at all temperatures were significantly $(\mathrm{P}<0.01)$ effect the appearance, flavor, palatability and texture of bread however; the results were non-significant in case of color of the bread. Among the temperatures, $14{ }^{0} \mathrm{C}$ showed more shelf life ( $370 \mathrm{hrs} / 15.44$ days) than other storage temperatures.

Key words: Chemical preservatives, Sensory evaluation, Bread
\end{abstract}

\section{INTRODUCTION}

Bread is the most important component of food. History reveals its use thousands of years even before the Christian era. Bread has played a key role in the development of humankind. The history of bread is lengthy and largely obscure. Clearly, bread was being consumed long before recorded history. Bread is made from wheat flour or other cereals by addition of water, salt and ferment (yeast). Wheat flour is best adopted for bread making, as it contains gluten in the right proportion to make the spongy loaf. Being deficient in fat, wheat bread is a preferred food. The quality of bread making is contingent upon availability of cereal flours to the consumer in an attractive, palatable and digestive form. The bread is prepared by baking portions of a kneaded mixture of crushed grain and water, usually with salt added to enhance flavor ${ }^{1}$. Bread is made by different procedures which depend upon many factors including tradition, cost, type of energy available, the type and consistency of the flour available, the type of bread desired and the time between baking and eating. To make bread one has to bake dough that consists of flour or grain meal. The flour or grain meal is mixed with water or milk. The people in many Western countries mainly bake loaves or rolls made with wheat flour. However, some people prefer to eat crispy and thin sheets of bread called flat bread in many parts of the world. Flat bread is made from grains like barley, corn, oats, rice, rye, wheat, or flour made from combination of these grains. Flat bread does not have yeast or other leavening agents to make it rise. Some people make bread by hand. In commercial bakeries bread is made by machine ${ }^{2}$.

In spite of multipurpose uses of bread, shelf life extension of bread is still a challenge. Thus, various ingredients or processes are used to extend the shelf life of bread aiming at to food legislations, ingredients availability, cost, consumer acceptance and social trends. Deterioration of bread includes staling, moisture loss or gain and microbial spoilage. The most common source of microbial spoilage is mould growth ${ }^{3,4}$. Viable vegetative moulds and mould spores are destroyed by the heat of the baking process, and their subsequent thermal inactivation. However, postbaking contamination occurs from the mould spores present in the atmosphere during handling operations such as cooling, finishing and wrapping ${ }^{5,6}$. Besides mould, bacterial and yeast spoilage may occur during storage ${ }^{7,8}$. Thus, it is evident that shelf life prolongation of bread is of great importance as it is related to the maintenance of fresh-keeping properties of bread and the productivity and profitability of a company.

Several methods of bread preservation are mentioned in the relevant literature including mould inhibitors (propionates, sorbates, dimethyl fumarate, acetates, ethanol), modified atmosphere packaging, pasteurization, infrared and ultraviolet irradiation, freezing etc. ${ }^{9-12}$. Selection of appropriate ingredients and adjustment of their levels in a bread recipe is a powerful tool, which leads to a significant inhibition of bread mould or microbial growth and therefore, extension of bread mould-free shelf life (MFSL) can be achieved ${ }^{13 a, b}$. Therefore, the manipulation of the levels of ingredients, used in a bread recipe, affects the shelf life. Sucrose is also a very important ingredient in bread recipes, because it is very effective in binding moisture as well as acting as an anti-staling agent. Increasing the sucrose level in bread recipes is not practical because of the inevitable excessive sweetness of bread and/or a possible imbalance within the recipe (recrystallised sugar and hygroscopicity of the surface). Salt on the other hand has powerful waterbinding properties because of its ionic structure. Even a relatively small quantity of salt could affect significantly the MFSL. However, there is a limit to the salt's quantity 
because of its strong effect on flavor, its negative effects on processing (e.g. changes in viscoelastic properties of gluten and inhibition of yeast in bread dough) and the social trend to unsalted or low-salted foods for potential health benefits ${ }^{5}$.

The use of preservatives in bread is also common and extensive all over the globe because of their effectiveness in preventing or inhibiting microbial spoilage in general and mould growth in particular. Although, healthy, additive-free' products are more attractive ${ }^{5}$. Preservatives do not significantly affect water activity, and their action depends on the product's $\mathrm{pH}$, product's composition, and storage temperature and water activity ${ }^{14}$. Potassium sorbate and calcium propionate are among the principal mould inhibitors used in bread and their inhibitory action has been extensively studied ${ }^{11,7}$. Potassium sorbate is effective up to $\mathrm{pH}$ 6. At higher $\mathrm{pH}$ levels, its effectiveness decreases significantly ${ }^{15}$. Calcium propionate is the most commonly used chemical antimicrobial and it is ideal for yeast-leavened bakery foods, as it is most effective at $\mathrm{pH}$ levels below 5.5. It is also very effective against spoilage caused by rope spores from bacteria Bacillus subtilis, surviving the baking process. The recommended level is within $0.19-0.32 \mathrm{~g} / 100 \mathrm{~g}$ flour. At higher application levels, calcium propionate imparts a distinct acid taste to bread $^{5}$. Ethanol, a strong bactericide, has recently been used for its effective preservative action in bread ${ }^{8,10 a, b}$. The addition of ethanol at levels $0.5 \%$ and $3.5 \%$ of loaf leads to a substantial extension of the shelf life of bread $^{13 \mathrm{~b}}$. Realizing the need to extend shelf-life of bread with the addition of chemical preservatives/bread improvers, this study was planned.

\section{MATERIALS AND METHODS}

The present study was carried out to investigate the effect of two different types of chemical preservatives on the sensorial quality of bread at various temperatures. The types of chemicals calcium propionate (Merck Germany) and calcium lactate (Merck Germany) procured from the local market of Hyderabad were used. They were added as an ingredient to create wheat flour at the time of dough preparation and development. The study was carried out in Bakery Technology Laboratory of Institute of Food Sciences and Technology, Sindh Agriculture University, Tandojam during 2008. The details of treatments are given are as under:

1. Preparation of dough with addition of Calcium propionate at the rate of 0.4 and $0.8 \mathrm{~g} \mathrm{~kg}^{-1}$ of flour.

2. Preparation of dough with addition of calcium lactate at the rate of 0.4 and $0.8 \mathrm{~g} \mathrm{~kg}^{-1}$ of flour.

3. Preparation of dough without the addition of chemical preservatives (control).

The separate batches of dough were prepared and breads were baked on the same day to evaluate their effect on the quality and storage period. The Sensory parameters were evaluated by panel of judges by scoring quality on score card for each parameter. On completion of their baking process, the breads were brought to the panel of judges for evaluation of appearance and color, flavor, texture and palatability separately for each chemical preservative as added in the wheat flour. The evaluation by judges was made through giving score on score card.

The samples of bread were stored at room temperature $\left(32^{\circ} \mathrm{C}\right.$, cold storage $\left(22^{\circ} \mathrm{C}\right)$ and cold storage $\left(14^{\circ} \mathrm{C}\right)$ to evaluate their shelf life in different storage conditions. The breads were examined on alternative days to see if there is bad odor or any infestation of fungus. The data collected on different storage conditions were analyzed statistically and presented in results section.

Table 1: Effect of different chemical preservative on the Sensorial quality of Appearance, Color, Flavor, Texture and Palatability of Bread

\begin{tabular}{|c|c|c|c|c|c|}
\hline Chemical Preservatives & Appearance & Color & Flavor & Texture & Palatability \\
\hline Control & $5.31 \mathrm{e}$ & 7.23 & $8.45 \mathrm{a}$ & $6.77 \mathrm{~d}$ & $7.24 \mathrm{~d}$ \\
\hline Calcium Propionate $0.4 \mathrm{~g}$ & $9.23 \mathrm{a}$ & 8.36 & $6.30 \mathrm{~d}$ & $7.42 \mathrm{c}$ & $7.52 \mathrm{c}$ \\
\hline Calcium Lactate $0.4 \mathrm{~g}$ & $8.30 \mathrm{~b}$ & 7.44 & $7.59 \mathrm{~b}$ & $7.65 \mathrm{c}$ & $7.30 \mathrm{c}$ \\
\hline Calcium Propionate $0.8 \mathrm{~g}$ & $7.28 \mathrm{c}$ & 7.67 & $7.32 \mathrm{c}$ & $8.84 \mathrm{a}$ & $9.27 \mathrm{a}$ \\
\hline Calcium Lactate $0.8 \mathrm{~g}$ & $6.31 \mathrm{~d}$ & 7.77 & $8.37 \mathrm{a}$ & $8.09 \mathrm{~b}$ & $8.58 \mathrm{~b}$ \\
\hline SE & 0.1158 & 0.1225 & 0.03937 & 1.247 & 0.02915 \\
\hline LSD AT 1\% & 0.5000 & - & 0.1701 & 5.732 & 0.1259 \\
\hline LSD AT 5\% & 0.3567 & - & 0.1213 & 3.990 & 0.08983 \\
\hline
\end{tabular}

Table 2: Effect of chemical preservatives on the cold Storage $\left(14 \pm 1^{\circ} \mathrm{C}\right)$ of Bread (hrs/days)

\begin{tabular}{|c|c|c|c|c|c|}
\hline \multirow[t]{2}{*}{ Chemical Preservatives } & \multicolumn{4}{|c|}{ Storage (Hours / Days) } & \multirow[t]{2}{*}{ Mean } \\
\hline & R1 & $\mathbf{R 2}$ & $\mathbf{R 3}$ & $\mathbf{R 4}$ & \\
\hline Control & $\begin{array}{c}264.00 \\
\text { (11.00 days) }\end{array}$ & $\begin{array}{c}270.00 \\
11.25 \text { days) } \\
\end{array}$ & $\begin{array}{c}274.00 \\
\text { (11.41 days) }\end{array}$ & $\begin{array}{c}268.00 \\
\text { (11.16 days) } \\
\end{array}$ & $\begin{array}{c}269.00 \mathrm{e} \\
(11.21 \text { days })\end{array}$ \\
\hline Calcium Propionate $0.4 \mathrm{~g}$ & $\begin{array}{c}336.00 \\
\text { (14.00days) }\end{array}$ & $\begin{array}{c}330.00 \\
\text { (13.75 days) }\end{array}$ & $\begin{array}{c}345.00 \\
(14.37 \text { days }) \\
\end{array}$ & $\begin{array}{c}342.00(14.25 \\
\text { days })\end{array}$ & $\begin{array}{c}338.00 \mathrm{c} \\
(14.09 \text { days })\end{array}$ \\
\hline Calcium Lactate $0.4 \mathrm{~g}$ & $\begin{array}{c}312.00 \\
\text { (13.00 days) }\end{array}$ & $\begin{array}{c}318.00 \\
(13.25 \text { days }) \\
\end{array}$ & $\begin{array}{c}320.00 \\
(13.33 \text { days })\end{array}$ & $\begin{array}{c}325.00(13.54 \\
\text { days })\end{array}$ & $\begin{array}{c}318.00 \mathrm{~d} \\
(13.28 \text { days })\end{array}$ \\
\hline Calcium Propionate $0.8 \mathrm{~g}$ & $\begin{array}{c}360.00 \\
\text { (15.00 days) }\end{array}$ & $\begin{array}{c}368.00 \\
\text { (15.33 days) }\end{array}$ & $\begin{array}{c}372.00 \\
\text { (15.56 days) }\end{array}$ & $\begin{array}{c}381.00 \\
\text { (15.87 days) } \\
\end{array}$ & $\begin{array}{c}370.00 \mathrm{a} \\
(15.44 \text { days }) \\
\end{array}$ \\
\hline Calcium Lactate $0.8 \mathrm{~g}$ & $\begin{array}{c}359.00 \\
\text { (14.95 days) }\end{array}$ & $\begin{array}{c}363.00 \\
\text { (15.12 days) }\end{array}$ & $\begin{array}{c}367.00 \\
(15.29 \text { days })\end{array}$ & $\begin{array}{c}370.00 \\
15.41 \text { days) }\end{array}$ & $\begin{array}{c}364.00 \mathrm{~b} \\
(15.19 \text { days })\end{array}$ \\
\hline SE & \multicolumn{5}{|c|}{$\mathbf{0 . 8 5 9 7}$} \\
\hline LSD at $1 \%$ & \multicolumn{5}{|c|}{3.714} \\
\hline LSD at 5\% & \multicolumn{5}{|c|}{2.649} \\
\hline
\end{tabular}


Table 3: Effect of chemical preservatives on the cold Storage $\left(22 \pm 1^{\circ} \mathrm{C}\right)$ of Bread (Hours/days)

\begin{tabular}{|c|c|c|c|c|c|}
\hline \multirow[t]{2}{*}{ Chemical Preservatives } & \multicolumn{4}{|c|}{ Storage (Hours / Days) } & \multirow[t]{2}{*}{ Mean } \\
\hline & R1 & $\mathbf{R 2}$ & R3 & $\mathbf{R 4}$ & \\
\hline Control & $\begin{array}{c}160.00 \\
\text { (6. } 66 \text { days) }\end{array}$ & $\begin{array}{c}167.00 \\
(6.95) \text { days }\end{array}$ & $\begin{array}{c}172.00 \\
\text { (7.16 days) }\end{array}$ & $\begin{array}{c}166.00 \\
\text { (6.91 days) }\end{array}$ & $\begin{array}{c}166.25 \mathrm{~d} \\
\text { (6.92days) }\end{array}$ \\
\hline Calcium Propionate $0.4 \mathrm{~g}$ & $\begin{array}{c}192.00 \\
(8.00 \text { days })\end{array}$ & $\begin{array}{c}188.00 \\
(7.83 \text { days })\end{array}$ & $\begin{array}{c}186.00 \\
(7.75 \text { days })\end{array}$ & $\begin{array}{c}190.00 \\
(7.91 \text { days })\end{array}$ & $\begin{array}{c}189.00 \mathrm{c} \\
(7.87 \text { days })\end{array}$ \\
\hline Calcium Lactate $0.4 \mathrm{~g}$ & $\begin{array}{c}187.00 \\
\text { (7.79 days) }\end{array}$ & $\begin{array}{c}189.00 \\
(7.87 \text { days })\end{array}$ & $\begin{array}{c}188.00 \\
(7.83 \text { days })\end{array}$ & $\begin{array}{c}186.00 \\
(7.75 \text { days })\end{array}$ & $\begin{array}{c}187.50 \mathrm{~b} \\
(7.81 \text { days })\end{array}$ \\
\hline Calcium Propionate $0.8 \mathrm{~g}$ & $\begin{array}{c}200.00 \\
\text { (8.33 days) }\end{array}$ & $\begin{array}{c}194.00 \\
\text { (8.08 days) }\end{array}$ & $\begin{array}{c}198.00 \\
(8.25 \text { days })\end{array}$ & $\begin{array}{c}196.00 \\
\text { (8.16 days) }\end{array}$ & $\begin{array}{c}197.00 \mathrm{a} \\
(8.21 \text { days })\end{array}$ \\
\hline Calcium Lactate $0.8 \mathrm{~g}$ & $\begin{array}{c}196.00 \\
(8.16 \text { days })\end{array}$ & $\begin{array}{c}194.00 \\
(8.08 \text { days })\end{array}$ & $\begin{array}{c}190.00 \\
(7.91 \text { days })\end{array}$ & $\begin{array}{c}197.00 \\
(8.20 \text { days })\end{array}$ & $\begin{array}{r}194.25 \mathrm{ab} \\
(8.09 \text { days }) \\
\end{array}$ \\
\hline \multicolumn{2}{|l|}{ SE } & \multicolumn{3}{|c|}{0.7781} & \\
\hline \multicolumn{2}{|l|}{ LSD at $1 \%$} & \multirow{2}{*}{\multicolumn{3}{|c|}{$\begin{array}{l}\mathbf{3 . 3 6 1} \\
\mathbf{2 . 3 9 7}\end{array}$}} & \\
\hline LSD at $5 \%$ & & & & & \\
\hline
\end{tabular}

\begin{tabular}{|c|c|c|c|c|c|}
\hline \multirow[t]{2}{*}{ Chemical Preservatives } & \multicolumn{4}{|c|}{ Storage (Hours / Days) } & \multirow[t]{2}{*}{ Mean } \\
\hline & R1 & $\mathbf{R 2}$ & R3 & R4 & \\
\hline Control & $\begin{array}{c}78.00 \\
\text { (3.25 days) }\end{array}$ & $\begin{array}{c}96.00 \\
\text { (4.00 days) }\end{array}$ & $\begin{array}{c}82.00 \\
\text { (3.41 days) } \\
\end{array}$ & $\begin{array}{c}84.00 \\
\text { (3.50 days) } \\
\end{array}$ & $\begin{array}{c}85.00 \mathrm{~d} \\
(3.54 \text { days })\end{array}$ \\
\hline Calcium Propionate $0.4 \mathrm{~g}$ & $\begin{array}{c}115.00 \\
(4.79 \text { days })\end{array}$ & $\begin{array}{c}110.00 \\
(4.58 \text { days })\end{array}$ & $\begin{array}{c}124.00 \\
(5.16 \text { days })\end{array}$ & $\begin{array}{c}112.00 \\
(4.66 \text { days) }\end{array}$ & $\begin{array}{c}115.25 \mathrm{~b} \\
(4.80 \text { days })\end{array}$ \\
\hline Calcium Lactate $0.4 \mathrm{~g}$ & $\begin{array}{c}96.00 \\
\text { (4.00 days) }\end{array}$ & $\begin{array}{c}104.00 \\
(4.33 \text { days })\end{array}$ & $\begin{array}{c}100.00 \\
(4.16 \text { days })\end{array}$ & $\begin{array}{c}108.00 \\
(4.50 \text { days })\end{array}$ & $\begin{array}{c}102.00 \mathrm{c} \\
(4.25 \text { days })\end{array}$ \\
\hline Calcium Propionate $0.8 \mathrm{~g}$ & $\begin{array}{c}120.00 \\
\text { (5.00 days) }\end{array}$ & $\begin{array}{c}126.00 \\
(5.25 \text { days })\end{array}$ & $\begin{array}{c}118.00 \\
(4.91 \text { days })\end{array}$ & $\begin{array}{c}128.00 \\
\text { (5.33 days) }\end{array}$ & $\begin{array}{c}123.00 \mathrm{a} \\
(5.12 \text { days })\end{array}$ \\
\hline Calcium Lactate $0.8 \mathrm{~g}$ & $\begin{array}{c}118.00 \\
\text { (4.91 days) }\end{array}$ & $\begin{array}{c}110.00 \\
\text { (4.58 days) }\end{array}$ & $\begin{array}{c}126.00 \\
\text { (5.25 days) }\end{array}$ & $\begin{array}{c}120.00 \\
\text { (5.00 days) }\end{array}$ & $\begin{array}{c}118.50 \mathrm{ab} \\
\text { (4.94 days) }\end{array}$ \\
\hline SE & & & 1.436 & & \\
\hline LSD at $1 \%$ & & & 6.205 & & \\
\hline LSD at $5 \%$ & & & 4.426 & & \\
\hline
\end{tabular}

Table 5: Effect of different chemical preservative on the palatability of Bread

\begin{tabular}{|c|c|c|c|c|c|}
\hline \multirow[t]{2}{*}{ Chemical Preservatives } & \multicolumn{4}{|c|}{ Palatability (Score) } & \multirow[t]{2}{*}{ Mean } \\
\hline & R1 & $\mathbf{R 2}$ & R3 & $\mathbf{R 4}$ & \\
\hline Control & 7.20 & 7.35 & 7.18 & 7.26 & $7.24 \mathrm{~d}$ \\
\hline Calcium Propionate $0.4 \mathrm{~g}$ & 7.65 & 7.45 & 7.64 & 7.37 & $7.52 \mathrm{c}$ \\
\hline Calcium Lactate $0.4 \mathrm{~g}$ & 7.39 & 7.42 & 7.23 & 7.19 & $7.30 \mathrm{c}$ \\
\hline Calcium Propionate $0.8 \mathrm{~g}$ & 9.25 & 9.28 & 9.41 & 9.17 & $9.27 \mathrm{a}$ \\
\hline Calcium Lactate $0.8 \mathrm{~g}$ & 8.87 & 8.64 & 8.35 & 8.49 & $8.58 \mathrm{~b}$ \\
\hline SE & \multicolumn{5}{|c|}{0.02915} \\
\hline LSD at $1 \%$ & \multicolumn{5}{|c|}{0.1259} \\
\hline LSD at $5 \%$ & \multicolumn{5}{|c|}{0.08983} \\
\hline
\end{tabular}

\section{RESULTS AND DISCUSSION}

The statistically analyzed mean values (Table 1) revealed that the appearance of bread was significant at $1 \%$ level of probability with the use of $\mathrm{CP}$ and $\mathrm{CL}$ at $0.4 \mathrm{~g} \mathrm{~kg}^{-1}$. Results showed that bread made with the addition of $\mathrm{CP}$ $0.4 \mathrm{~g} \mathrm{~kg}^{-1}$ at $14{ }^{0} \mathrm{C}$ exhibited the best appearance followed by CL $0.4 \mathrm{~g}$, CP 0.8 and $\mathrm{CL} 0.8 \mathrm{~g} \mathrm{~kg}^{-1}$ respectively. The highest scores for quality appearance was obtained 9.23 by $\mathrm{CP}$ and 8.30 by CL. The lower scores for appearance was recorded in control (no preservative) samples as 5.31. The results are non-significant $(\mathrm{P}>0.05)$.

Regarding color of bread, the application of CP with the concentration of $0.4 \mathrm{~g}$ and CL $0.8 \mathrm{~g}$ showed good scores at $14^{0} \mathrm{C}$ i.e. 8.36 and 7.77 respectively. However, CP with the concentration of $0.8 \mathrm{~g}$ and CL $0.4 \mathrm{~g} \mathrm{~kg}^{-1}$ were showed comparatively poorer color with a scoring of 7.67 and 7.44 respectively. The results further revealed that the effect of CP and CL at both the concentrations of 0.4 and $0.8 \mathrm{~g} \mathrm{~kg}^{-1}$ had no statistically significant effect but the bread prepared with $\mathrm{CP}$ at $0.4 \mathrm{~g}$ received higher score i.e. 8.36 followed by CL $0.8 \mathrm{~g}$ with a score of 7.77 . The lowest value of 7.23 for color of bread was recorded in control. However, CP $0.8 \mathrm{~g}$ and $\mathrm{CL} 0.4 \mathrm{~g} \mathrm{~kg}^{-1}$ were awarded third and fourth position with the scores of 7.67 and 7.44 respectively (Table 2 ).

The data collected on flavor of bread is presented in Table-3. Results showed that flavor of bread in control treatment was significantly superior at $(\mathrm{P}<0.01)$ followed by $\mathrm{CL}$ in the concentration of $0.8 \mathrm{~g} \mathrm{~kg}^{-1}$. However, CL 0.4 , CP 0.8 and CP $0.4 \mathrm{~g}$ showed poor flavor Furthermore, the data indicated that the best flavor of bread was obtained in control treatment scoring 8.45 followed by CL at $0.8 \mathrm{~g}$ scoring 8.37 points. The lowest point of 6.30 for flavor of bread was recorded in the bread prepared with CP at the concentration of $0.4 \mathrm{~g} \mathrm{~kg}^{-1}$. The results are highly significant $(\mathrm{P}<0.001)$.

The data obtained on texture of bread is presented in Table 4. The data indicated that the bread prepared with chemical preservative of calcium propionate at concentration of $0.8 \mathrm{~g}$ at $14^{0} \mathrm{C}$ recorded highest scores of 8.84 for texture as compared to other treatments. Calcium lactate at $0.8 \mathrm{~g}$ concentration ranked second in texture with scores of 8.09. Calcium propionate and Calcium lactate at $0.4 \mathrm{~g}$ concentration resulted lower scores i.e. 7.42 and 7.65 points respectively. The result are highly significant for texture of bread $(\mathrm{P}<0.001)$. Likewise, the data obtained on 
palatability of bread is presented in Table-5. The data gathered on palatability of bread prepared with addition of $\mathrm{CP}$ and $\mathrm{CL}$ showed that $\mathrm{CP}$ at $0.8 \mathrm{~g}$ got highest scores i.e. 9.27 as compared to other chemical preservatives. The second highest score was 8.45 for the palatability of bread was recorded in $\mathrm{CL}$ at $0.8 \mathrm{~g}$ concentration. The lowest value was 7.24 recorded for palatability of bread prepared under control treatment. However, $\mathrm{CP}$ and $\mathrm{CL}$ at concentration of $0.4 \mathrm{~g}$ received lower scores for palatability of bread. The results are highly significant for texture of bread $(\mathrm{P}<0.001)$.

\section{CONCLUSION}

From the research, it may be concluded that fortification of $\mathrm{CP}$ and $\mathrm{CL}$ at $0.8 \mathrm{~g}$ at $14{ }^{0} \mathrm{C}$ (cold storage) showed better quality of bread with improved physicochemical properties and extensive shelf life.

\section{ACKNOWLEDGEMENT}

Authors acknowledge the assistance of the staff of Institute of Food Sciences and Technology and management of Sindh Agriculture University Tandojam for allowing and providing ever possible facilities for conducting this research.

\section{REFERENCES}

1. Ammirati JF. World Book Encyclopedia, Mold 1999

2. Hillers VN. Storing foods at hom, Washington State University Cooperative Extension, Pullman, WA. Publ. EB 1993; 1205-1206

3. Pyler EJ. Baking Science and Technology, Vol II, 3rd edn. Kansas, KS: Sosland Publishing Company, 1988; 210-236.

4. Legan JD and Voisey PA. Yeast spoilage of bakery products and ingredients. Journal of Applied Bacteriology 1991; 70: 361-371. http://dx.doi.org/10.1111/j.1365-2672.1991.tb02950.x PMid:1874683

5. Doerry WT. Breadmaking Technology. Manhatttan, NY: American Institute of Baking 1995; 156-159.
6. Yang TCS. Ambient storage. In: Food Storage and Stability (edited by I.A. Taub). New York, NY: CRC Press, 1998 ; 436-438.

7. Grundy JG. Preservatives. In: Baked Goods Freshness. Technology, Evaluation and Inhibition of Staling (edited by E.H. Ronald \& F.Z. Henry). New York, NY: Marcel Dekker Inc 1996; 189-204.

8. Pateras IM. Bread spoilage and staling. In: Technology of Breadmaking (edited by S.P. Cauvain \& L.S. Young) 1999; 240 244.

9. Islam MN. Inhibition of mold in bread by dimethyl fumarate. Journal of Food Science 1982; 47: 1710-1712. http://dx.doi.org/ 10.1111/j.1365-2621.1982.tb05017.x

10a.Matz SA. Bakery Technology. Amsterdam: Elsevier Science Publishers 1989a;135-167.

10b.Matz SA. Technology of the Materials of Baking. Amsterdam: Elsevier Science Publishers 1989b; 260-262.

11. Legan JD. Mould spoilage of bread: the problem and some solutions. International Biodeterioration and Biodegradation 1993; 32: 33-53. http://dx.doi.org/10.1016/0964-8305(93)90038-4

12. Seiler DAL. Bakery products. In: Principles and Applications of Modi.ed Atmosphere Packaging of Foods (edited by B.A. Blakistone). Blackie Academic \& Professional London, 1998; 135157

13a.Doulia DF, Rigas and Katsinis G. Multiparametric investigation of mould-free shelf life of bread via factorial design, International Journal of Food Properties 2000a; 3: 363-374 http://dx.doi.org/ $\underline{10.1080 / 10942910009524641}$

13b.Doulia DG, Katsinis and Mougin B. Prolongation of the microbial shelf life of wrapped part-baked baguettes, International Journal of Food Properties 2000b; 3: 447-457. http://dx.doi.org/ $\underline{\text { 10.1080/10942910009524648 }}$

14. Davidson PM. Control of microorganisms with chemicals. In: Control of Food borne Microorganisms (edited by V.K. Juneja \& J.N. Sofos). New York, NY: Marcel Dekker 2002; 165-190

15. Sofos JN. Sorbic acid. In: Natural Food Antimocrobial Systems (edited by A.S. Naidu). New York, NY: CRC Press. 2000; 637-659.

\section{Cite this article as:}

Muhammad Shahnawaz, Dileep Kumar Lohano and Saghir Ahmed Sheikh. A study on the impact of Chemical preservatives on sensorial excellence of bread at various temperatures. Int. J. Res. Ayur. Pharm. $2012 ; 3(6): 833-836$ 